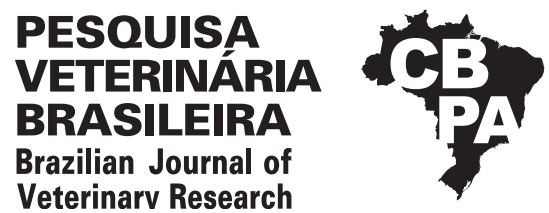

Pesq. Vet. Bras. 40(1):1-6, January 2020 DOI: 10.1590/1678-5150-PVB-6351

Original Article Veterinarv Research Livestock Diseases

ISSN 0100-736X (Print)

ISSN 1678-5150 (Online)

\title{
Spontaneous and experimental poisoning by Froelichia humboldtiana in cattle ${ }^{1}$
}

\author{
Givaldo B. Silva Filho' ${ }^{2}$, Hisadora A.S. Chaves², Raquel F. Albuquerque ${ }^{2}$, \\ Paulo E. Souza ${ }^{3}$, Maria E.Q. Vieira ${ }^{4}$, Ana L.O. Nascimento ${ }^{5}$, Stephanie C. Lima ${ }^{5}$ \\ and Fábio S. Mendonça ${ }^{5 *}$ (i)
}

\begin{abstract}
Silva Filho, G.B.S., Chaves H.A.S., Albuquerque R.F., Souza P.E., Vieira M.E.Q., Nascimento A.L.O., Lima S.C. \& Mendonça F.S. 2020. Spontaneous and experimental poisoning by Froelichia humboldtiana in cattle. Pesquisa Veterinária Brasileira 40(1):1-6. Laboratório de Diagnóstico Animal, Universidade Federal Rural de Pernambuco, Rua Dom Manoel de Medeiros s/n, Dois Irmãos, Recife, PE 52171-900, Brazil. E-mail: fabio.mendonca@pq.cnpq.br

The aim of this work was to describe the epidemiological, clinical and pathological aspects of two outbreaks of spontaneous poisoning caused by Froelichia humboldtiana in cattle in Pernambuco, northeastern Brazil and reproduce experimentally this poisoning in cattle. Spontaneous poisonings of primary photosensitization occurred in two farms at the municipalities of Cachoeirinha and São Caetano and affected twenty-two adult bovines and two suckling calves after the rainy season. All bovines have recovered 21 days after they were removed from the pasture. To reproduce experimental poisoning, three cows and a calf were maintained in a pasture with 1 ha composed by F. humboldtiana during 14 days. Clinical signs and skin lesions were similar in both spontaneous and experimental poisoning and consisted of cutaneous itching and hyperemia of non-pigmented areas of skin that evolved into edema, exudative dermatitis and extensive areas of skin necrosis. Serum levels of aspartate aminotransferase (AST), gamma glutamyltransferase (GGT), total, direct and indirect bilirubin were normal in all cattle examined. Histologically, lesions consisted of epidermal necrosis, hyperkeratosis with large amounts of degenerate neutrophils and acanthosis. In the dermis, edema and inflammatory infiltrate composed of eosinophils, lymphocytes and plasma cells mainly around the blood vessels were observed. In the experimental group, clinical signs of photosensitization were observed after the third day of $F$. humboldtiana consumption. The suckling calf displayed mild clinical signs of photodermatitis on the 8th day of the experiment. It was estimated that the average consumption of $F$. humboldtiana necessary to initiate clinical signs in each adult bovine was $78 \mathrm{~kg}$.
\end{abstract}

INDEX TERMS: Spontaneous poisoning, experimental poisoning, Froelichia humboldtiana, cattle, poisonous plants, skin, photodermatitis, poisoning, toxic plants, toxicoses.

\footnotetext{
${ }^{1}$ Recceived on May 15, 2019.

Accepted for publication on July 10, 2019.

${ }^{2}$ Graduate Program in Veterinary Medicine, Universidade Federal Rural de Pernambuco (UFRPE), Rua Dom Manoel de Medeiros s/n, Dois Irmãos, Recife, PE 52171-900, Brazil.

${ }^{3}$ Empresa de Assistência Técnica e Extensão Rural da Paraíba, Rua Leonel Coelho 34, Pedro Gondim, João Pessoa, PB 58031-050, Brazil.

${ }^{4}$ Departamento de Zootecnia, Universidade Federal Rural de Pernambuco (UFRPE), Rua Dom Manoel de Medeiros s/n, Dois Irmãos, Recife, PE 52171-900.

${ }^{5}$ Laboratório de Diagnóstico Animal, Universidade Federal Rural de Pernambuco (UFRPE), Rua Dom Manoel de Medeiros s/n, Dois Irmãos, Recife, PE 52171-900. *Corresponding author: fabio.mendonca@pq.cnpq.br
}

RESUMO. [Intoxicação espontânea e experimental por Froelichia humboldtiana em bovinos.] Os objetivos deste trabalho foram descrever os aspectos epidemiológicos, clínicos e patológicos de dois surtos de intoxicação por Froelichia humboldtiana em bovinos em Pernambuco e reproduzir experimentalmente essa intoxicação em bovinos. Intoxicações espontâneas foram observadas após o início do período chuvoso nos municípios de Cachoerinha e São Caetano. Vinte e dois bovinos apresentaram sinais clínicos e lesões cutâneas compatíveis com fotossensibilização primária, 
dentre os quais, dois bezerros lactentes. Todos os bovinos se recuperaram totalmente cerca de 21 dias após serem retirados da pastagem. Para reproduzir experimentalmente a intoxicação, três vacas, uma delas com bezerro ao pé, foram mantidas em um piquete de 1 ha composto por F. humboldtiana por 14 dias consecutivos. 0 quadro clínico e as lesões tegumentares, tanto nos bovinos intoxicados nos surtos espontâneos, quanto nos bovinos do experimento consistiram em prurido e hiperemia em áreas despigmentadas de pele, que evoluíam para edema, dermatite exsudativa e necrose de áreas extensas de pele. Em todos os bovinos examinados, os níveis séricos de aspartato aminotransferase (AST), gamaglutamiltransferase (GGT), bilirrubina total, direta e indireta estavam normais. Histologicamente, as lesões consistiram em necrose da epiderme, hiperqueratose com grande quantidade de neutrófilos degenerados e acantose. Na derme havia edema e infiltrado inflamatório composto por eosinófilos, linfócitos e plasmócitos principalmente ao redor dos vasos sanguíneos. Nos bovinos do experimento, sinais clínicos de fotossensibilização foram observados após o terceiro dia de consumo de $F$. humboldtiana. $\mathrm{O}$ bezerro lactente apresentou sinais clínicos leves de fotodermatite no 8o dia do experimento. Estimou-se que o consumo médio de matéria seca de F. humboldtiana necessário para iniciar os sinais clínicos em cada bovino adulto foi de $78 \mathrm{~kg}$.

TERMOS DE INDEXAÇÃO: Intoxicação espontânea, intoxicação experimental, Froelichia humboldtiana, bovinos, plantas tóxicas, pele, fotodermatite, toxicoses.

\section{INTRODUCTION}

Photosensitization is an important cause of dermatitis resulting from the interaction between a photosensitizing agent and ultraviolet (UV) radiation or visible light (Tokarnia et al. 2012). It can be classified in two types in farmed animals: primary, as a result of photodynamic substances ingestion and, secondary, or hepatogenic, as a aftereffect of liver damage mainly generated by saponins and sapogenins (Pimentel et al. 2007, Tokarnia et al. 2012, Knupp et al. 2014, 2018, Santos et al. 2017, Amado et al. 2018, Moreira et al. 2018).

Froelichia humboldtiana (Amaranthaceae), commonly known as "ervanço", is widely distributed of the Brazilian northeastern region (Pimentel et al. 2007, Souza et al. 2012, Santos et al. 2017, Amado et al. 2018, Knupp et al. 2018), being thus responsible for primary photosensitization outbreaks. Horses are mainly poisoned (Pimentel et al. 2007, Knupp et al. 2014, Amado et al. 2018), however cattle, sheep and goats could be also affected (Pimentel et al. 2007, Souza et al. 2012, Santos et al. 2017).

The most noticeable clinical signs are hyperemia and itching on depigmented skin patches. These areas are swollen, presented exudative dermatitis, ulcers, tissue necrosis with extensive areas skin loss (Pimentel et al. 2007, Souza et al. 2012, Santos et al. 2017, Amado et al. 2018, Knupp et al. 2018). Weight loss and decreased milk production in cows and does occur concurrently (Santos et al. 2017, Knupp et al. 2018).

Photosensitization outbreaks are common in semiarid region of Brazil. However, despite its importance for ruminants and horses (Amado et al. 2018), the disease is not diagnosed frequently in the State of Pernambuco. This study aimed to describe the epidemiological, clinical and pathological aspects of two outbreaks of spontaneous poisoning caused by F. humboldtiana in cattle in Pernambuco, northeastern Brazil and reproduce experimentally this poisoning in cattle.

\section{MATERIALS AND METHODS}

Spontaneous poisoning. Outbreaks of spontaneous poisoning by Froelichia humboldtiana (Fig.1) occurred in the municipalities of Cachoeirinha and São Caetano in the dry region of the State of Pernambuco. Epidemiological data was obtained through interviews with the owners during the visit in the farms. Additionally, in order to find poisonous plants, the pastures of these farms were inspected. During the visits, affected cattle were clinically evaluated and skin biopsies and blood samples were collected. Skin biopsies were performed on three most severely affected animals of each property and the fragments fixed in $10 \%$ formalin, routinely processed for histopathology, stained with hematoxylin and eosin (HE) and evaluated by light microscopy. Blood samples were collected by jugular venipuncture to determine serum levels of aspartate aminotransferase (AST), gamma glutamyltransferase (GGT), total, direct and indirect bilirubin.

Experimental poisoning. For the experiment the guides related to animal welfare and ethics were followed, as recommended by

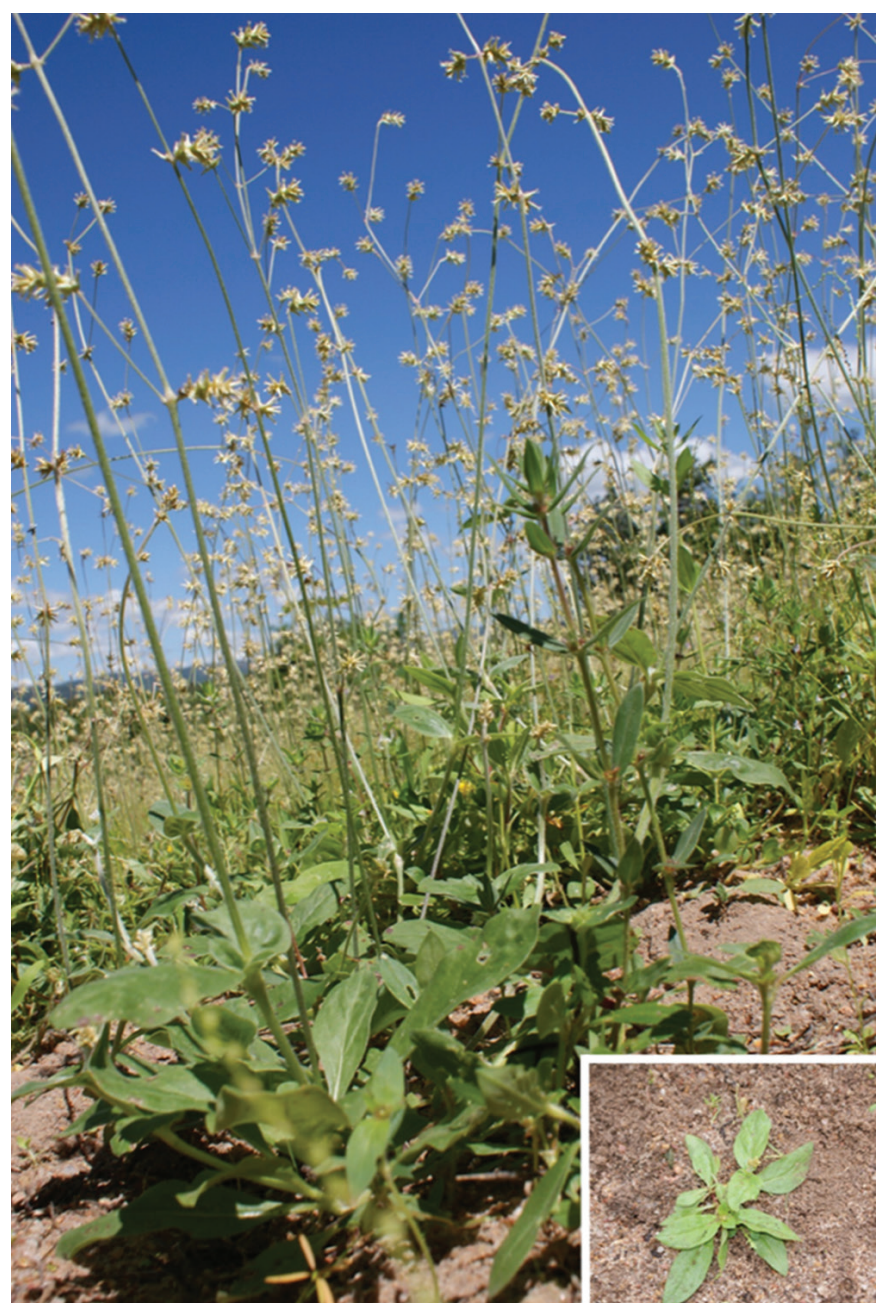

Fig.1. Froelichia humboldtiana, an erect or decumbent sub-bushes with 0.5-1.5m of high. Inset: F. humboldtiana sprout. Cachoeirinha/PE, August 2017. 
the National Council for the Control of Animal Experimentation (CONCEA) and the Ethics Committee on the Use of Animals of the "Universidade Federal Rural de Pernambuco" (CEUA-UFRPE) (Authorization 014/2013).

The experiment was conducted on a farm in the municipality of Salgado de São Félix, State of Paraíba. Three adult crossbred Holstein cows, mean weighing $300 \mathrm{~kg}$ were used. One of them had a two months suckling calf. Before the beginning of the experiment, all animals were clinically evaluated by examination of behavior, heart and respiratory rates, ruminal motility and inspection of the body surface for the occurrence of skin lesions. This physical examination was repeated daily until the end of the experiment.

The animals were fasted for 24 hours before being introduced into a grazing enclosure of 1 hectare (10000 square meters) consisting of $F$. humboldtiana, where they remained for 14 days. In this area there were no other species of plants causing photosensitization. Throughout the experimental period the animals received commercial mineral salt for cattle and water ad libitum.

Samples of F. humboldtiana were collected and sent to the zootechnical department of UFRPE for bromatological analysis. In order to estimate the amount of $F$. humboldtiana required to induce clinical signs, the dry matter daily intake was considered at 3\% of cow's body weight (Hargreaves \& Kerr 1981) and the estimated dry matter daily intake weight was $9 \mathrm{~kg}$ per adult cow. This data was applied to the following formula:

$$
F=\frac{9 K g \times 100}{D M}
$$

Where: $\mathrm{F}=$ Forage daily intake and $\mathrm{DM}=\% \mathrm{~F}$. humboldtiana dry matter.

Skin biopsies were performed on the 16 th day of the experiment in all adult cattle. These samples were fixed in 10\% formalin, routinely processed for histology and evaluated by light microscopy. Blood samples were collected at the beginning and at the end of the experiment to determine serum levels of AST, GGT, total, direct and indirect bilirubin as previously described.

\section{RESULTS}

\section{Spontaneous poisoning}

Two outbreaks occurred in August 2017 during the rainy season and farmers reported these were the first outbreaks of this disease in the municipalities. Due to the prolonged drought period farmers had not seeded the pastures and after first rains, Froelichia humboldtiana strongly invaded cattle's grazing areas. In both farms a large amount of $F$. humboldtiana with cattle grazing signs were observed.

The farm located in the municipality of Cachoeirinha had 50 Girolando dairy cattle grazing in approximately $147 \mathrm{ha}$. Clinical signs were only noted by the owner 8 days after introduction of the herd in a pasture composed of native vegetation with large amount of $F$. humboldtiana. Fourteen animals showed clinical signs: two males, ten females and two suckling calves, whose mothers also had photosensitization. These clinical signs consisted of photophobia, intense itching, hyperemia, alopecia, ulcers and crusts on skin, mostly in white skin areas. Additionally, dairy cows showed intense hyperemia, ulceration of teats/udder, decreased milk production and weight loss.

In São Caetano eight from a total of 60 crossbred Nelore cattle were affected in a farm with approximately 200 ha. The first clinical signs began 11 days after introduction of the herd into a pasture previously composed of Brachiaria spp. and native vegetation; however, after prolonged drought and with the first rains, $F$. humboldtiana invaded the pasture areas. The clinical signs consisted of licking and alopecia due to intense skin's itching that evolved to ulcerative, necrotizing and exudative dermatitis with loss of extensive areas of skin, especially in the flanks and inguinal region (Fig.2).

Microscopically the lesions were similar in the two outbreaks and consisted of epidermal necrosis (Fig.3), hyperkeratosis with large amounts of degenerated neutrophils and moderate to severe acanthosis. In the dermis edema, inflammatory infiltrate consisting of eosinophils, lymphocytes and plasma cells mainly around blood vessels and thrombosis were observed. Serum levels of AST, GGT and total, direct and indirect bilirubin concentrations were within the reference values for the bovine species in all blood samples analyzed.

After primary photosensitization diagnosis, all cattle have been removed from the pasture invaded by F. humboldtiana to a shaded facility with a supply of napier grass (Pennisetum purpureum). The cutaneous lesions of affected cattle in both outbreaks regressed in 10 days.
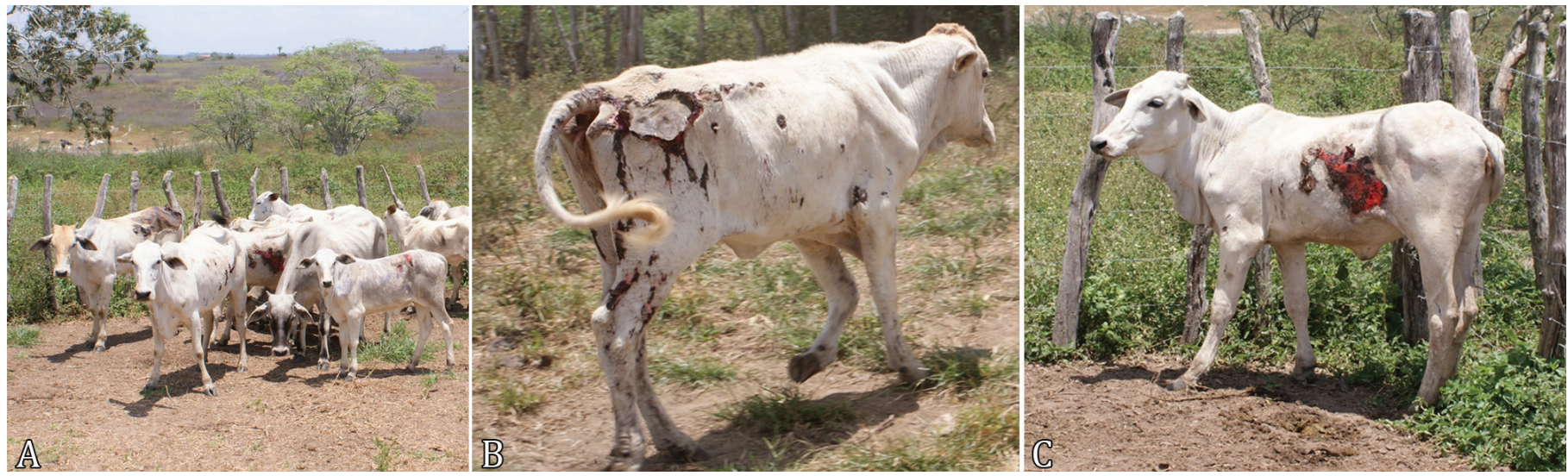

Fig.2. (A) Several cattle from a herd showing alopecia, ulcerative, necrotizing and exudative dermatitis, with loss of extensive areas of the epidermis, especially in the non-pigmented areas of skin in the (B) hindlimbs and (C) flanks. 


\section{Experimental poisoning}

From the second day of experiment (DE) cattle showed discrete clinical signs consisting of restlessness and an attempt to remain as long as possible in shaded areas. Between 3rd and 5 th DE, the cows repetitively compressed flank, lateral side of the face and posterior region against fences and tree trunks due to itching. In this period, it was possible to observe cutaneous lesions that consisted of alopecia and hyperemia of depigmented areas of skin, mostly in the head, dorsal portion of the neck, withers and proximal portion of the hind limbs. In 8th DE, the calf presented slight lesions of photodermatitis, which consisted of alopecia and hyperemia of the barb and other areas of white skin. In cows, lesions evolved to edema and skin necrosis between the 8th and 17th DE (Fig.4).

No changes were observed in the heart rate, respiratory or ruminal motility in experimental cattle. The microscopy lesions consisted of areas of skin ulceration. The epidermis was covered by fibrin with neutrophil infiltrate and several superficial bacterial aggregates. Inflammatory infiltrate composed of mast cells, lymphocytes and some plasma cells were observed in the superficial dermis, especially around vessels. The serum levels of AST, GGT and concentrations of total, direct and indirect bilirubin were normal in all experimental cattle.

It was estimated that the average daily DM consumption of each adult animal was $9 \mathrm{~kg}$. As F humboldtiana DM was estimated at $35 \%$, it is suggested that each experimental cattle had ingested approximately $26 \mathrm{~kg}$ of $F$. humbolditiana per day. The amount of $F$. humboldtiana ingested until present the first clinical signs on the 3rd DE was approximately $78 \mathrm{~kg}$ per adult cattle.

Once the experiment ended, all cattle were removed from the pasture containing $F$. humboldtiana, placed in shaded facility and received buffel grass (Cenchrus ciliaris), napier grass (Pennisetum purpureum), commercial -ration, mineral salt for cattle and water. From 7 to 12 days later, the skin lesions regressed and totally recovered after 23 days.

\section{DISCUSSION}

The diagnosis of primary photosensitization due to Froelichia humboldtiana consumption in cattle of this study was based on epidemiological, clinical and histopathological findings that was similar to those reported previously (Pimentel et al. 2007, Souza et al. 2012, Knupp et al. 2014, Santos et al. 2017, Amado et al. 2018). Malachra fasciata, a species of poisonous
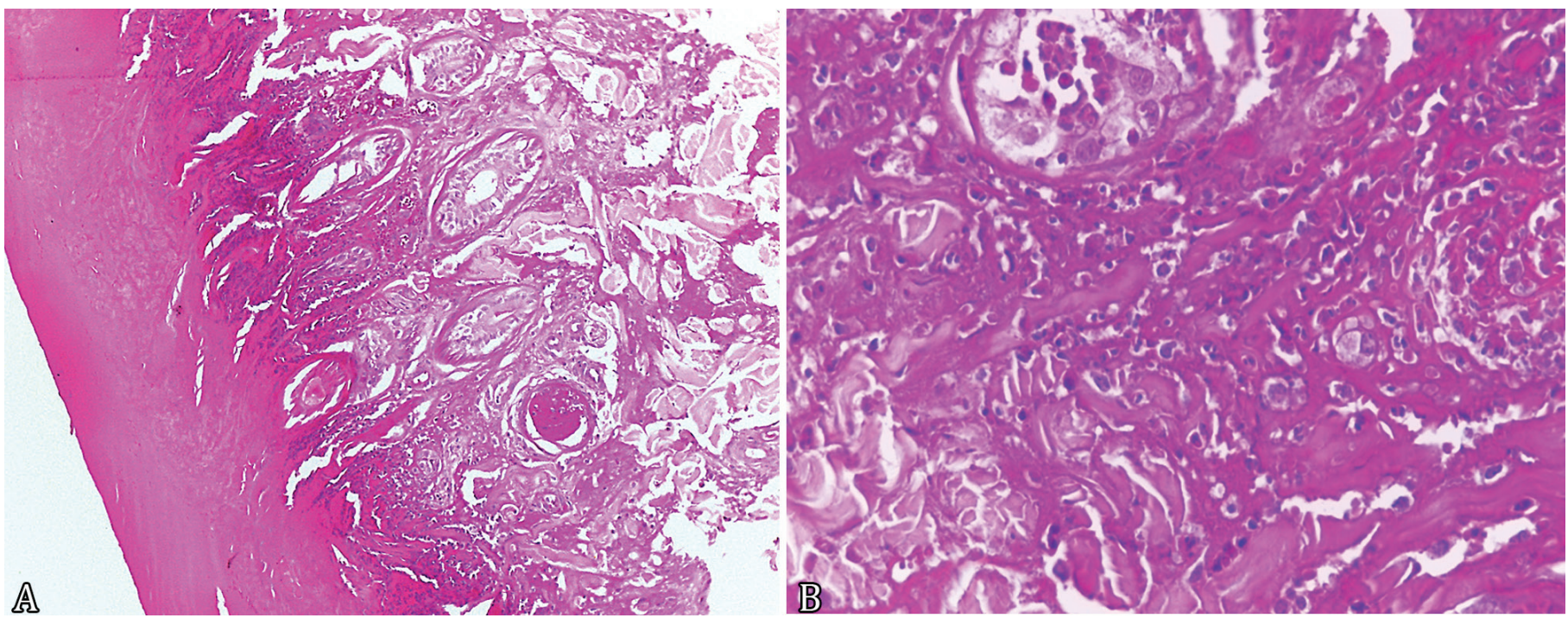

Fig.3. (A) Extensive coagulation necrosis of the epithelial tissue with thrombosis in the superficial dermis. HE, obj.10x. (B) Infiltrate composed by lymphocytes, plasma cells and eosinophils in superficial dermis. HE, obj.40x.
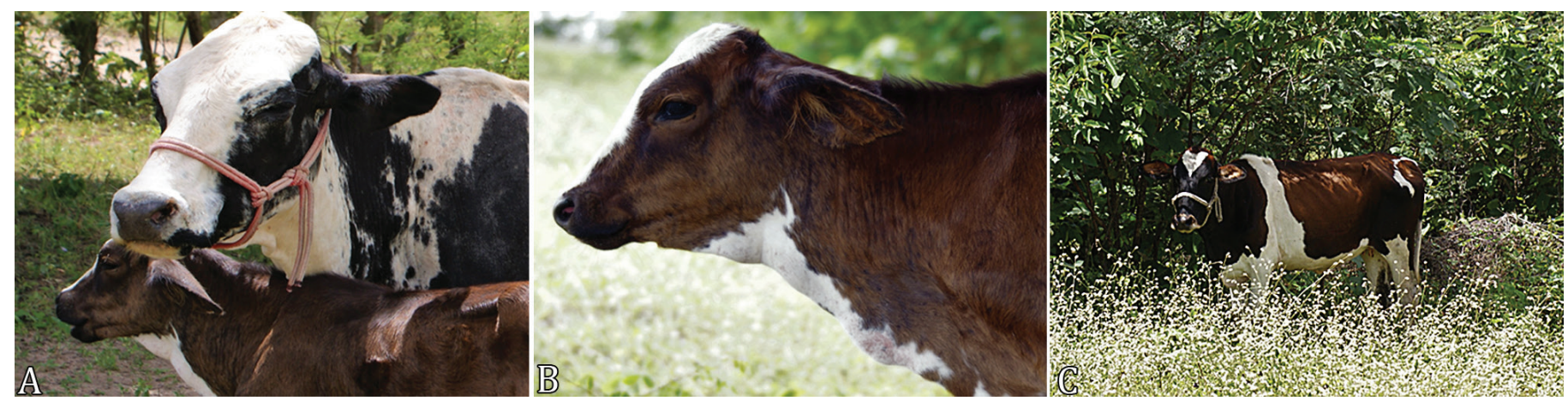

Fig.4. (A) Cutaneous lesions of Froelichia humboldtiana poisoning in the 8th day of experiment. Note the alopecia and hyperemia of depigmented areas of the skin near to the dorsal portion of the neck of the cow and (B) edema and alopecia of the calf barb. (C) Cow showing photophobia, remaining the most part of the day in a shaded area on the 3rd day of experimental poisoning. 
plant that causes primary photosensitization also occurs in Pernambuco. However, this species was not found during pasture inspections and nowadays cases of photodermatitis were only described in sheep (Araújo et al. 2017). In northeastern Brazil, poisonings by Brachiaria spp., Crotalaria spp. and Enterolobium contortisiquum are also important for cattle (Amado et al. 2018). However, these plants cause secondary photosensitization, and hepatic injuries can be diagnosed by biopsies or by serum biochemistry analysis.

Serum levels profiles of AST, GGT and bilirubin's, are important tools to distinguish primary and secondary photosensitization because elevated concentrations are observed when significant damages are present in the liver (Knupp et al. 2014, 2018). These profiles remain within the normal range in cases of primary photodermatitis (Souza et al. 2012, Knupp et al. 2016, 2018).

The extended period of drought in the region studied, along with the occurrence of first rains, the lack of knowledge about the good palatability and toxicity of $F$. humboldtiana for cattle and the incorrect management of the pastures were important factors for the occurrence of primary photosensitization outbreaks described in this study. In these cases, correct pasture management could have prevented outbreaks, as it would not allow F. humboldtiana grows too much in the grazing lands.

In this study, affected cows as well as their suckling calves presented a clinical picture and characteristic lesions of primary photosensitization. This information, reported by farmers, was observed in two calves from spontaneous outbreaks and was reproduced in a calf from the experiment that presented mild dermatitis. The toxic principle of $F$. humboldtiana is unknown, but it is suggested that naftodiantrones may be related to the pathogenesis of tegumentary lesions (Pimentel et al. 2007). Other toxins from Brazilian plants can be excreted in milk, such as pyrrolizidine alkaloids, steroidal saponins, monocrotaline, ptaquiloside, and tremogenic toxin from Ipomoea asarifolia (Dickinson et al. 1976, James 1994, Medeiros \& Górniak 1995, Lemos et al. 1998, Lopes et al. 2014, Lucena et al. 2014).Therefore, the possibility of $F$. humboldtiana toxin(s) being excreted by the milk of poisoned cows should be investigated better, since this characteristic was not observed in previous studies in cows (Knupp et al. 2018) and dairy goats (Santos et al. 2017).

In this study, it was estimated that each cow used in the experiment consumed 26kg of $F$. humboldtiana per day and showed clinical signs on the 3rd DE. This is an important result because although there are other experimental studies demonstrating the toxicity of $F$. humboldtiana to cattle, none of them have suggested what its toxic dose would be (Souza et al. 2012, Medeiros et al. 2014).

None of cattle in spontaneous outbreaks died or even in experimental poisonings. This characteristic is expected in cases of primary photosensitization, since the lesions are restricted only to the skin (Pimentel et al. 2007, Souza et al. 2012). Cases of death have been reported in asinines and were associated with self-mutilation or opportunistic agents, such as bacteria and myiasis (Knupp et al. 2014). Secondary photosensitization frequently occurs only in light-haired animals, but as a result of hepatic injury and high mortality has been reported in animals regardless of coat color (Macêdo et al. 2008, Knupp et al. 2016, Amado et al. 2018, Moreira et al. 2018).

\section{CONCLUSION}

It was concluded that Froelichia humboldtiana intake was indicated as the cause of primary photosensitization in cattle in the municipalities of Cachoeirinha and São Caetano in the State of Pernambuco. Suckling calves whose mothers graze on pasture areas invaded by the plant also be affected.

Acknowledgments.- To the FACEPE (Process APQ-0202- 5.05/17), CAPES (Finance Code 001) and CNPq (Process 304804/2018-5) for granting the necessary financial support for the development of this study.

Conflict of interest statement.- The authors have no conflicts of interest to declare.

\section{REFERENCES}

Amado G.P., Silva C.C.B., Barbosa F.M.S., Nascimento H.H.L., Malta K.C., Azevedo M.V., Lacerda-Lucena P.B. \& Lucena R.B. 2018. Surtos de fotossensibilização e dermatite alérgica em ruminantes e equídeos no Nordeste do Brasil. Pesq. Vet. Bras. 38(5):889-895. <http://dx.doi.org/10.1590/1678-5150-pvb-5583>

Araújo V.O., Oliveira Neto T.S., Simões S.V.D., Silva T.K.F., Riet-Correa F. \& Lucena R.B. 2017. Primary photosensitization and contact dermatitis caused by Malachra fasciata Jacq. N.V. (Malvaceae) in sheep. Toxicon 138:184-187. <http://dx.doi.org/10.1016/j.toxicon.2017.09.009> <PMid:28918228>

Dickinson J.O., Cooke M.P., King R.R. \& Mohamed P.A. 1976. Milk transfer of pyrrolizidine alkaloids in cattle. J. Am. Vet. Med. Assoc. 169(11):1192 1196. <PMid:1002587>

Hargreaves J.N.G. \& Kerr J.D. 1981. Botanal: a comprehensive sampling and computing procedure for estimating pasture yield and composition. II Computational package. Division of Tropical Crops and Pastures, CSIRO Brisbane. 88p.

James L.F. 1994. Solving poisonous plant problems by a team approach, p.1-6. In: Colegate S.M. \& Dorling P.R. (Eds), Plant Associated Toxins. CAB International, Wallingford.

Knupp S.N.R., Knupp L.S., Riet-Correa F. \& Barbosa R.L. 2016. Plants that cause photosensitivity in ruminants in Brazil. Semina, Ciênc. Agrárias 37(4):2009-2020.

Knupp S.N.R., Borburema C.C., Oliveira Neto T.D., Medeiros R.D., Knupp L.S. Riet-Correa F. \& Lucena R.B. 2014. Surtos de fotossensibilização primária em equídeos causados por Froelichia humboldtiana. Pesq. Vet. Bras. 34(12):11911195. <http://dx.doi.org/10.1590/S0100-736X2014001200008>

Knupp S.N., Borburema C.C., Araújo V.O., Silva T.K.F., Riet-Correa F., Knupp L.S. \& Lucena R.B. 2018. Primary photosensitization in dairy cattle caused by Froelichia humboldtiana. Pesq. Vet. Bras. 38(5):811-816. <http://dx.doi org/10.1590/1678-5150-pvb-5238>

Lemos R.A.A., Nakazato L., Herrero Junior G.O., Silveira A.C. \& Porfírio L.C 1998. Fotossensibilização e colangiopatia associada a cristais em caprinos mantidos sob pastagens de Brachiaria decumbens no Mato Grosso do Sul. Ciência Rural 28(3):507-510. <http://dx.doi.org/10.1590/S0103$84781998000300026>$

Lopes J.R.G., Riet-Correa F., Cook D., Pfister J.A. \& Medeiros R.M.T. 2014 Elimination of the tremorgenic toxin of Ipomoea asarifolia by milk Pesq. Vet. Bras. 34(11):1085-1088. <http://dx.doi.org/10.1590/S0100736X2014001100009>

Lucena K.F.C., Rodrigues J.M.N., Campos É.M., Dantas A.F.M., Pfister J.A., Cook D., Medeiros R.M.T. \& Riet-Correa F. 2014. Poisoning by Ipomoea asarifolia in lambs by the ingestion of milk from ewes that ingest the plant Toxicon 92:129-132. <http://dx.doi.org/10.1016/j.toxicon.2014.10.019> <PMid:25448387>

Macêdo J.T.S.A., Riet-Correa F., Dantas A.F.M. \& Simões S.V.D. 2008. Doenças da pele em caprinos e ovinos no semiárido brasileiro. Pesq. Vet. Bras. 28(12):633-642.<http://dx.doi.org/10.1590/S0100-736X2008001200013> 
Medeiros R.M.T. \& Górniak S.L. 1995. Efeitos da administração de sementes de Crotalaria spectabilis e monocrotalina (MCT) na ração de ratas em lactação, no desenvolvimento físico de seus filhotes. Revta Soc. Bras. Toxicologia, IX Congresso Brasileiro de Toxicologia, Ribeirão Preto, SP, p.296. (Resumo)

Medeiros R.M.T., Bezerra V.K.D. \& Riet-Correa F. 2014. Intoxicação experimental por Froelichia humboldtiana em equinos. Ciência Rural 44(10):1837-1840. <http://dx.doi.org/10.1590/0103-8478cr20131417>

Moreira N., Martin C.C., Hilgert A.R., Tostes R.A. \& Viott A.D.M. 2018. Fotossensibilização hepatógena em bovinos por ingestão de Brachiaria decumbens. Arch. Vet. Sci. 23(1):52-62. <http://dx.doi.org/10.5380/avs. v23i1.41659>

Pimentel L.A., Riet-Correa F., Guedes K.M., Macêdo J.T., Medeiros R.M. \& Dantas A.F. 2007. Fotossensibilização primária em equídeos e ruminantes no semiárido causada por Froelichia humboldtiana (Amaranthaceae). Pesq. Vet. Bras. 27(1):23-28. <http://dx.doi.org/10.1590/S0100-736X2007000100005>

Santos D.S., Silva C.C., Araújo V.O., Souza M.F., Lacerda-Lucena P.B., Simões S.V., Riet-Correa F. \& Lucena R.B. 2017. Primary photosensitization caused by ingestion of Froelichia Humboldtiana by dairy goats. Toxicon 125:65-69. <http://dx.doi.org/10.1016/j.toxicon.2016.11.258><PMid:27890773>

Souza P.E., Oliveira S.S., Aguiar-Filho C.R., Cunha A.L., Albuquerque R.F., EvêncioNeto J., Riet-Correa F. \& Mendonça F.S. 2012. Primary photosensitization in cattle caused by Froelichia humboldtiana. Res. Vet. Sci. 93(3):1337-1340. <http://dx.doi.org/10.1016/j.rvsc.2012.04.005> <PMid:22575746>

Tokarnia C.H., Brito M.F., Barbosa J.D., Peixoto P.V. \& Döbereiner J. 2012. Plantas/micotoxinas fotossensibilizantes, p.305-348. In: Ibid. (Eds), Plantas Tóxicas do Brasil. 2ª ed. Editora Helianthus, Rio de Janeiro. 